\title{
eLyra
}

REVISTA DA REDE INTERNACIONAL LYRACOMPOETICS

Vilma Arêas

\section{Instruções de voo}

homenagem à Adília

Suspeito que seja difícil brincar com ela. Talvez por uma questão de ritmo. Talvez porque ela não tenha modos. Ah, quem me dera um vestido que me queimasse - ela disse há muitos anos. Eu também. Quem me dera. E um coquetel de café com leite e bofetadas, servido em copos altos. Por isso ela provoca tanta alegria diabólica. O convite para espatifar caras porcelanas. Espatifar as inconfessáveis virtudes de fulanos e beltranos. Talvez até mesmo as metafísicas virtudes de sicranos. Mas uma dúvida às vezes me perturba: isto será poesia? Isto será mesmo poesia? Não será simplesmente orgia infantil?

Ah, brincar até nunca! Quem não sabe que as crianças verdadeiras -as falsas são um constrangimento- só se tornam crianças depois de mil anos de vida dura? Depois de um trabalho de sol a sol? Picasso disse mais ou menos assim: se quer escrever, feche os olhos e desenhe. Também disse que levamos muito tempo para nos tornarmos jovens, quanto mais crianças. E alguns morrem sem nunca haver conseguido, sem nunca ter sofrido o insuportável brilho do esplendor na relva.

Brincar até nunca! Como as crianças, levantar a saia num gesto de homenagem, dizer duas ou três porcarias e lamber os beicinhos besuntados com o grave, o doce, o insubstituível chocolate da desobediência. Uma alegria misteriosa chove então sobre nós, como o maná no deserto, um dia. Mas desobedecer a que ou a quem?

- faça o que eu digo e não faça que eu faço. 
- faça o que eu faço e não faça o que eu digo.

- faço o que digo e não faço o que faço.

- faço o que faço e não faço o que digo.

As palavras agora levantaram voo e estão a pique de desaparecer lá em cima, no canto alto da página. Mas atenção: quem escolher a alternativa errada vai desabar, atropelando a terza rima, nas alastradas paragens infernais. 